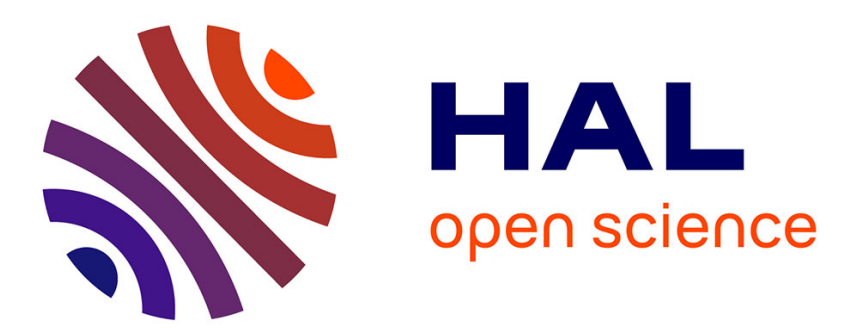

\title{
Pulp Fibroblasts Control Nerve Regeneration through Complement Activation
}

\author{
F. Chmilewsky, I. About, S.-H. Chung
}

\section{To cite this version:}

F. Chmilewsky, I. About, S.-H. Chung. Pulp Fibroblasts Control Nerve Regeneration through Complement Activation. Journal of Dental Research, 2016, 95 (8), pp.913-922. 10.1177/0022034516643065Journal . hal-03547296

\section{HAL Id: hal-03547296 \\ https://hal.science/hal-03547296}

Submitted on 28 Jan 2022

HAL is a multi-disciplinary open access archive for the deposit and dissemination of scientific research documents, whether they are published or not. The documents may come from teaching and research institutions in France or abroad, or from public or private research centers.
L'archive ouverte pluridisciplinaire HAL, est destinée au dépôt et à la diffusion de documents scientifiques de niveau recherche, publiés ou non, émanant des établissements d'enseignement et de recherche français ou étrangers, des laboratoires publics ou privés. 


\title{
Pulp Fibroblasts Control Nerve Regeneration through Complement Activation
}

\author{
F. Chmilewsky', I. About ${ }^{2}$, and S.-H. Chung'
}

\begin{abstract}
Dentin-pulp regeneration is closely linked to the presence of nerve fibers in the pulp and to the healing mechanism by sprouting of the nerve fiber's terminal branches beneath the carious injury site. However, little is known about the initial mechanisms regulating this process in carious teeth. It has been recently demonstrated that the complement system activation, which is one of the first immune responses, contributes to tissue regeneration through the local production of anaphylatoxins such as C5a. While few pulp fibroblasts in intact teeth and in untreated fibroblast cultures express the C5a receptor (C5aR), here we show that all dental pulp fibroblasts, localized beneath the carious injury site, do express this receptor. This observation is consistent with our in vitro results, which showed expression of $\mathrm{C5aR}$ in lipoteichoic acid-stimulated pulp fibroblasts. The interaction of $\mathrm{C5}$ a, produced after complement synthesis and activation from pulp fibroblasts, with the $\mathrm{C} 5 \mathrm{aR}$ of these cells mediated the local brain-derived neurotropic factor (BDNF) secretion. Overall, this activation guided the neuronal growth toward the lipoteichoic acid-stimulated fibroblasts. Thus, our findings highlight a new mechanism in one of the initial steps of the dentin-pulp regeneration process, linking pulp fibroblasts to the nerve sprouting through the complement system activation. This may provide a useful future therapeutic tool in targeting the fibroblasts in the dentin-pulp regeneration process.
\end{abstract}

Keywords: pulp biology, axon outgrowth, receptor biology, innate immunity, caries, cell biology

\section{Introduction}

The success of dentin-pulp regeneration is directly correlated to the presence of nerve fibers in the dentin-pulp complex and to the sprouting of their terminal branches into the surviving pulp beneath the injured site (Kimberly and Byers 1988; Arai 1991). This nerve sprouting can enhance inflammation and healing processes by immune cell recruitment and vascular permeability at the injured site (Byers and Nähri 1999; Hanoun et al. 2015). It has long been established that tissue regeneration is closely linked to inflammation, as demonstrated by a significant tissue regeneration inhibition when corticosteroids are used in case of myocardial infarction (Kloner et al. 1978). In accordance with these data, it has been demonstrated that dentin-pulp regeneration is directly associated with the presence of nerve fibers in pulp tissue since an occlusal exposure induces more pulp necrosis in denervated than innervated teeth (Byers and Taylor 1993). The duration and extent of dental nerve sprouting depend on the nature and intensity of the injury and seem to be regulated by the spatiotemporal modulation of growth factor expression in the pulp (Taylor et al. 1988; Woodnutt et al. 2000). However, although dental nerve sprouting appears to have a critical importance in dentin-pulp regeneration, very little is known about initial molecular events controlling this process.

Recently, it has been demonstrated that the complement system, a major component of innate immunity and inflammation, is activated at the injured site of carious teeth (Chmilewsky,
Jeanneau, Laurent, et al. 2014). While complement is known to be activated from plasma proteins, it is also efficiently activated in human teeth from proteins produced by pulp fibroblasts (Chmilewsky, Jeanneau, Laurent, et al. 2014). In addition, it became evident that complement, especially through the active fragment $\mathrm{C} 5 \mathrm{a}$, participates in tissue regeneration, as demonstrated in the liver (Mastellos et al. 2011), bone (Ignatius et al. 2011), teeth (Chmilewsky et al. 2013; Chmilewsky, Jeanneau, Laurent, et al. 2014), and cardiac tissues (Lara-Astiaso et al. 2012). Interestingly, few in vivo and in vitro studies demonstrated that $\mathrm{C} 5 \mathrm{a}$, through its interaction with the $\mathrm{C} 5 \mathrm{a}$ receptor $(\mathrm{C} 5 \mathrm{aR})$, is directly involved in the modulation of several growth factors expression. Thus, in a retinal fibrosis mouse model, C5a-C5aR interaction induced a

\footnotetext{
'Department of Oral Biology, University of Illinois at Chicago, Chicago, IL, USA

${ }^{2}$ Aix-Marseille Université, CNRS, ISM, UMR 7287, Marseille cedex 09, France

\section{Corresponding Author:}

S.-H. Chung, Department of Oral Biology, College of Dentistry, University of Illinois at Chicago, 80I S. Paulina St., Chicago, IL 606/2, USA.

Email: chungsh@uic.edu
} 
significant production of platelet-derived growth factor and transforming growth factor $\beta$ (Boor et al. 2007). Also, it has been demonstrated that $\mathrm{C} 5$ a stimulates the expression of vascular endothelial growth factor by retinal Müller cells in vitro (Cheng et al. 2013). Based on these data, we hypothesized that the complement activation through $\mathrm{C} 5 \mathrm{aR}$ could be one of the initial signals in dental nerve sprouting under carious decays.

\section{Materials and Methods}

\section{Materials}

See Appendix.

\section{Molar Collection}

Human immature third molars, freshly extracted for orthodontics reasons, and carious teeth were obtained in compliance with French legislation (informed patients' consent and institutional review board approval of the protocol used). Teeth were fixed and routinely processed as previously described (Téclès et al. 2005).

\section{Immunohistochemistry}

Before tooth sections were stained, antigen retrieval and saturation were performed as previously described (Chmilewsky, Jeanneau, Laurent, et al. 2014). Then tooth sections were incubated for $1 \mathrm{~h}$ with anti-C5aR $(20 \mu \mathrm{g} / \mathrm{mL})$, anti- $\beta$-III-tubulin $(1 \mu \mathrm{g} / \mathrm{mL})$, or their respective isotype control.

C5aR immunostaining was done by incubating sections for 45 min with Alexa Fluor 488 anti-mouse immunoglobulin G (IgG) $(2 \mu \mathrm{g} / \mathrm{mL})$ and 4',6-diamidino-2-phenylindole (DAPI) $(1 \mu \mathrm{g} / \mathrm{mL})$ counterstain.

$\beta$-III-tubulin immunostaining was done by incubating sections for $2 \mathrm{~h}$ with horseradish peroxidase (HRP)-conjugated anti-rabbit (1:200). Diaminobenzidine (DAB, $0.5 \mathrm{mg} / \mathrm{mL}$ ) was used to visualize the reaction.

Some sections were stained with hematoxylin-eosin.

\section{Cell Cultures}

Human pulp cells were prepared from immature third molars at the 2/3-root formation stage by the explant outgrowth method and cultured as previously described (About et al. 2000). Human neurons (HNs) were cultured in neuronal medium supplemented with neuronal growth supplement, $100 \mu \mathrm{g} / \mathrm{mL}$ streptomycin, and $100 \mathrm{U} / \mathrm{mL}$ penicillin.

\section{Immunofluorescence Staining}

Pulp cells were seeded overnight at $12.5 \times 10^{3}$ cells $/ \mathrm{cm}^{2}$ on 8 -well culture chambers before incubation in serum-free medium \pm lipoteichoic acid (LTA) $(1 \mu \mathrm{g} / \mathrm{mL})$. After 6- or 24 -h incubation, cells were fixed with $4 \%$ paraformaldehyde (10 min), permeabilized with phosphate-buffered saline (PBS) $/ 0.3 \%$ Tween-20/0.3\% glycine (30 min), and saturated with $3 \%$ bovine serum albumin (BSA) $(1 \mathrm{~h})$. Then, cells were incubated $1 \mathrm{~h}$ with a mix of anti-C5aR $(10 \mu \mathrm{g} / \mathrm{mL})+$ anti-fibroblast surface protein (FSP) $(20 \mu \mathrm{g} / \mathrm{mL})$, anti-C $5 \mathrm{aR}(5 \mu \mathrm{g} / \mathrm{mL})+$ antiphospho-C5aR(pSer338) $(10 \mu \mathrm{g} / \mathrm{mL})$, or their respective control isotypes. Finally, cells were incubated for $40 \mathrm{~min}$ with a mix of Alexa Fluor 594 anti-mouse $\mathrm{IgG}$, Alexa Fluor 488 anti-rabbit IgG $(2 \mu \mathrm{g} / \mathrm{mL})$, and DAPI $(1 \mu \mathrm{g} / \mathrm{mL})$. The coverslips were sealed and photographs taken (DMI6000 B microscope; Leica).

\section{In-Cell Western Assay}

Pulp cells were seeded at $15 \times 10^{3}$ cells $/ \mathrm{cm}^{2}$ in 96 -well plates. At subconfluency, cells were incubated in serum-free medium $\pm \mathrm{LTA}(1 \mu \mathrm{g} / \mathrm{mL})$ and \pm W54011 $(10 \mathrm{nmol} / \mathrm{L})$ for $24 \mathrm{~h}$. Then, cells were immediately fixed with $100 \%$ cold methanol (15 min) and saturated with 5\% BSA (1.5 h). Cells were incubated overnight at $4^{\circ} \mathrm{C}$ with anti-C5aR $(5 \mu \mathrm{g} / \mathrm{mL})$, anti-phospho-C5aR(pSer338) $(10 \mu \mathrm{g} / \mathrm{mL})$, or their respective control isotypes. Cells were then washed $(0.05 \%$ Tween-20/PBS $)$ and incubated with respective IRDye-680RD secondary antibody (1 h). After 5 washes, plates were scanned at $700 \mathrm{~nm}$ (Odyssey CLx).

\section{Neurotrophin Quantifications}

Pulp cells were seeded at $15 \times 10^{3}$ cells $/ \mathrm{cm}^{2}$ in 12 -well plates. At subconfluency, cells were incubated in serum-free medium $(300 \mu \mathrm{L}) \pm \mathrm{LTA}(1 \mu \mathrm{g} / \mathrm{mL})$ and $\pm \mathrm{W} 54011(10 \mathrm{nmol} / \mathrm{L})$. After 6,24 , and $48 \mathrm{~h}$, brain-derived neurotrophic factor (BDNF) concentrations in supernatant were determined by enzyme-linked immunosorbent assay (ELISA) according to the manufacturer's instructions. Results were normalized to the cell viability (determined by the 3-[4, 5-dimethylthiazolyl-2]-2, 5-diphenyltetrazolium bromide [MTT] assay as described in Chmilewsky, Jeanneau, Laurent, et al. 2014).

\section{Neurite Outgrowth Assay}

Neurite outgrowth was investigated using AXon Investigation Systems (AXIS), as described (Fig. 1; for detailed protocol, see Appendix).

\section{Statistical Analysis}

All experiments were repeated at least 3 times $(n=3)$, and statistical significance was determined using the Student's $t$ test. Data were expressed as means $\pm \mathrm{SD}$ and considered significant for $P<0.05$.

\section{Results}

\section{C5aR Is Expressed in Carious Teeth and Colocalized with Nerve Terminal Endings}

We first investigated the expression of $\mathrm{C} 5 \mathrm{aR}$ both in intact (Fig. 2A) and carious tooth sections (Fig. 2B). While few or no 
C5aR expression was detected in intact tooth sections (Fig. 2C, D), an intense staining was specifically observed in the inflamed pulp beneath the carious site (Fig. 2E, F). A higher magnification reveals that all pulp cells localized beneath the injured site expressed C5aR (Fig. 2F) while very little or no $\mathrm{C} 5 \mathrm{aR}$ expression was detected in pulp far from injury site (Fig. 2G, H). Nerve fiber localization was investigated on the same tooth sections through $\beta$-III-tubulin staining, a differentiated neuron marker (Tao et al. 2015). In intact teeth, $\beta$-III-tubulin was mainly localized beneath the odontoblast cell layer (Fig. 2I, J). In carious teeth, a densification of nerve extensions was detected beneath the injured site (Fig. 2K). Indeed, an intense staining characteristic of transverse and longitudinal sectioned nerve structures was clearly observed at higher magnifications (Fig. 2L). Labeling at a distance from the carious site was similar to that in intact teeth (Fig. 2M, N). These results show that $\mathrm{C} 5 \mathrm{aR}$ expression is correlated to nerve fiber sprouting in carious teeth.

\section{C5aR Is Expressed in LTA- Stimulated Pulp Fibroblasts}

Since Gram-positive bacteria constitute the predominant cariogenic bacteria (Martin et al. 2002), LTA was used to simulate the presence of these bacteria in the pulp. All pulp cells used in our experiments expressed the FSP marker (Fig. $3 \mathrm{Aa}-\mathrm{c})$; hereafter, these cells will be designated as pulp fibroblasts. Consistent with our in vivo results, we observed that few pulp fibroblasts expressed C5aR (Fig. 3Ad). After 6-h and 24-h LTA stimulation, all pulp fibroblasts expressed the

surface (red box) was chosen to illustrate the process of neurite outgrowth analyses. (b) Neurons, localized inside $C_{\text {central }}$, extend neurites toward $C_{\text {left }}$ and $C_{\text {right }}$ through migrogrooves. (c) A manual tracking of neurite growth was performed from the neuron nucleus inside $C_{\text {central }}$ to terminal neurite extension, which is localized either inside the microgroove or inside $C_{\text {right }} / C_{\text {left }}$. (d) Neurite trajectories are reported in a graphic representing lengths in micrometers, so that each cell nucleus position is localized at $(0 ; 0)$ coordinates.

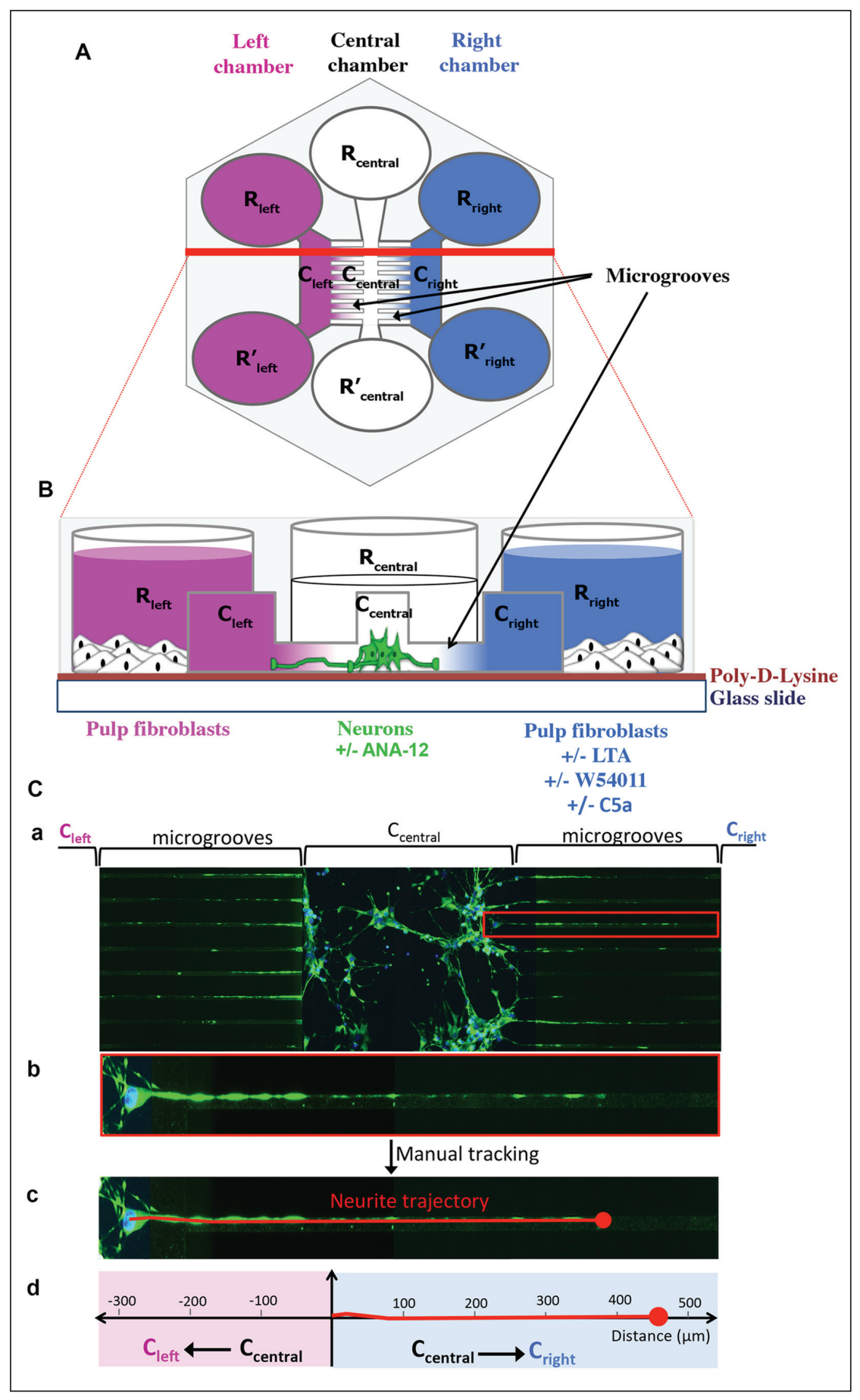

Figure I. Schematic representations of an Axon Investigation System (AXIS). (A) The neurite outgrowth device is made of 2 peripheral chambers (left and right chambers) and a central chamber. Each of these chambers is composed by 2 reservoirs $\left(R_{\text {left }}\right.$ and $R_{\text {left }}^{\prime} ; R_{\text {central }}$ and $R^{\prime}{ }_{\text {central }}$; $R_{\text {right }}$ and $R_{\text {right }}^{\prime}$ ) interconnected by a thin channel (respectively, $C_{\text {left }}, C_{\text {central }}$, and $C_{\text {right }}$ ). $C_{\text {central }}$ communicates with $C_{\text {left }}$ and $C_{\text {right }}$ through thin microgrooves $(500 \times 10 \times 5 \mu \mathrm{m})$. (B) An AXIS cross-section: devices were disposed on a glass slide previously coated with poly-D-lysine. Human neurons were seeded into $C_{\text {central }}$; human pulp fibroblasts were seeded into the reservoirs of the 2 peripheral chambers (i.e., $R_{\text {left }}, R_{\text {left }}^{\prime}, R_{\text {right }}$, and $R_{\text {right }}^{\prime}$ ). $C_{\text {left }}$ and $C_{\text {right }}$ were left empty of cells. Pulp fibroblasts of the right chamber were incubated \pm lipoteichoic acid (LTA), \pm C5a, and \pm W5 50 II , a C5aR-specific antagonist, in serum-free medium. Human neurons of the central chamber were incubated in neural medium \pm ANA- 12 (a tropomyosin receptor kinase B antagonist). (C) Neurite outgrowth visualization and analysis. (a) Fluorescent microscopic view of an analyzed area: neurite outgrowth assays were run for $48 \mathrm{~h}$, and then a $\beta$-IIl-tubulin staining was performed. A reduced 


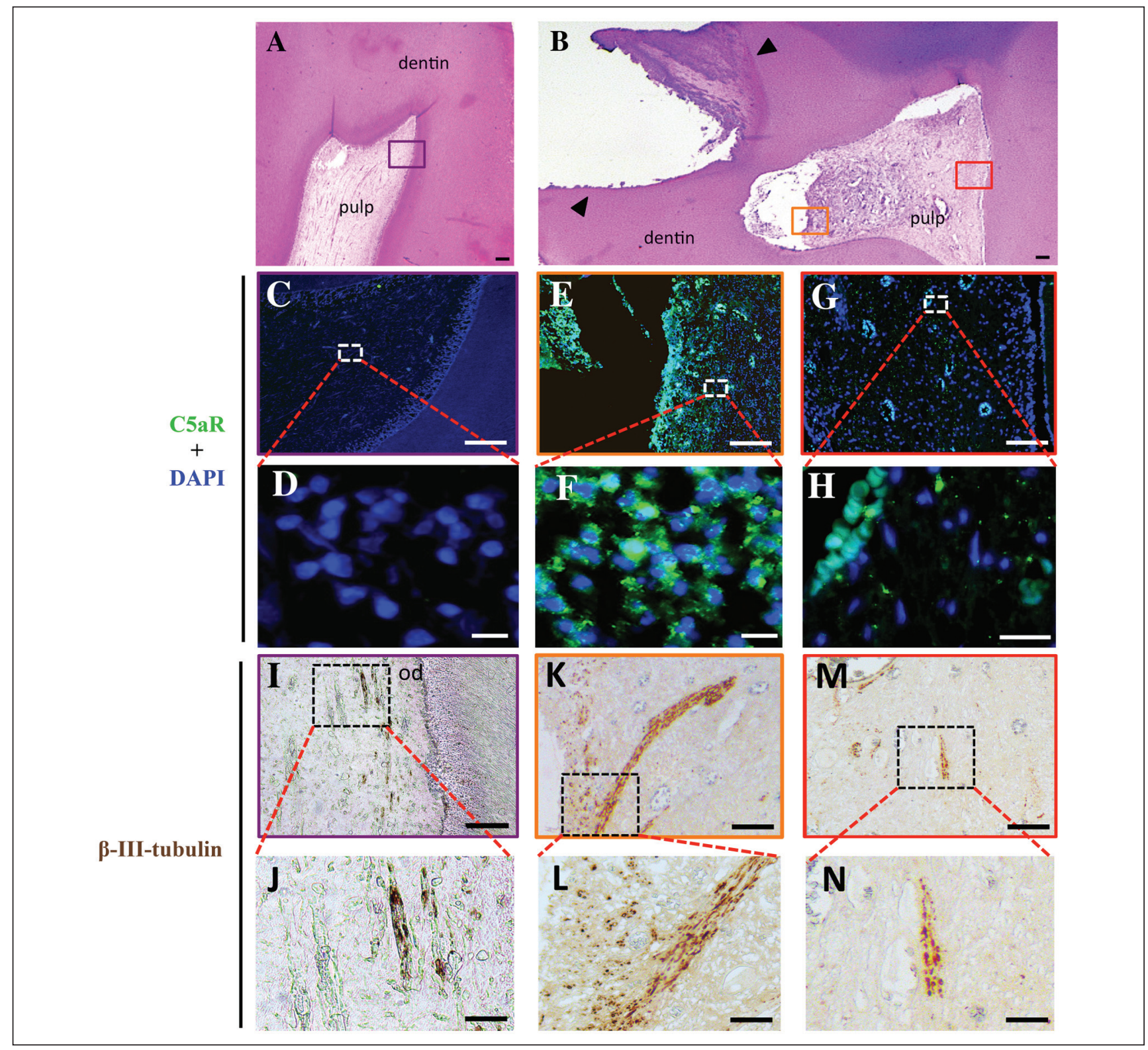

Figure 2. Expression of $\mathrm{C} 5 \mathrm{aR}$ and $\beta$-III-tubulin in vivo. Immunohistochemistry was used to investigate the expression of $\mathrm{C} 5 \mathrm{aR}$ and $\beta$-III-tubulin in intact $(\mathbf{A})$ and carious teeth (B). (C-H) Fluorescent detection of C5aR. While C5aR was not detected in intact teeth (C, D), its labeling was intense in carious teeth beneath the carious injuries $(\mathrm{E}, \mathrm{F})$. The observation at higher magnification shows clearly an expression of $\mathrm{C} 5 \mathrm{R}$ by all the cells localized beneath the carious injured sites (F). C5aR staining was not detected at a distance from the carious lesions (G, H). (I-N) Chromogenic detection of $\beta$-III-tubulin. In intact teeth, $\beta$-III-tubulin was mainly detected beneath the odontoblast cell layer (I, J). In carious teeth, an intense staining was observed beneath injured sites $(\mathrm{K}, \mathrm{L})$; comparatively, its labeling was low in the healthy area of carious teeth $(\mathrm{M}, \mathrm{N})$. A and B: Hematoxylin-eosin stain. $\mathrm{C}$ to $\mathrm{H}$ : Nuclei were counterstained with 4',6-diamidino-2-phenylindole (DAPI) (blue). Symbols: arrowheads indicate caries lesion; OD indicates odontoblast cell layer. $C$ and I, magnified from the purple box in $A ; E$ and $K$ magnified from the orange box in $B ; G$ and $M$ magnified from the red box in $B$. Scale bars: $A, B=500 \mu \mathrm{m} ; \mathrm{C}, \mathrm{E}, \mathrm{G}, \mathrm{I}, \mathrm{K}$, and $\mathrm{M}=200 \mu \mathrm{m} ; \mathrm{D}, \mathrm{F}$, and $\mathrm{H}=20 \mu \mathrm{m} ; \mathrm{J}, \mathrm{L}$, and $\mathrm{N}=50 \mu \mathrm{m}$.

C5aR (Fig. 3Ae, f). Merge images show that only LTA-stimulated fibroblasts expressed C5aR (Fig. 3Ag-i). Higher magnification of C5aR staining (Fig. 3Aj-1) indicated that $6 \mathrm{~h}$ after LTA stimulation, C5aR was mainly detected around the nucleus (Fig. 3Ak), whereas after $24 \mathrm{~h}$, it was principally localized at cell membranes and in the cytoplasm (Fig. 3Al). Moreover, our in-cell Western assays (Fig. 3Ba, b) revealed that the C5aR staining in pulp fibroblasts was significantly higher 6 and $24 \mathrm{~h}$ after LTA stimulation than in untreated conditions. Taken together, these results indicate that there is a new expression of $\mathrm{C} 5 \mathrm{aR}$ in LTA-stimulated fibroblasts.

\section{C5aR Is Activated in LTA-Stimulated Pulp Fibroblasts}

We next decided to investigate the ability of C5a generated by LTA-stimulated pulp fibroblasts (Chmilewsky, Jeanneau, Laurent, et al. 2014) to activate their own C5aR. Unlike untreated fibroblasts (Fig. 4Aa-d), an intense phospho-C5aR and C5aR 


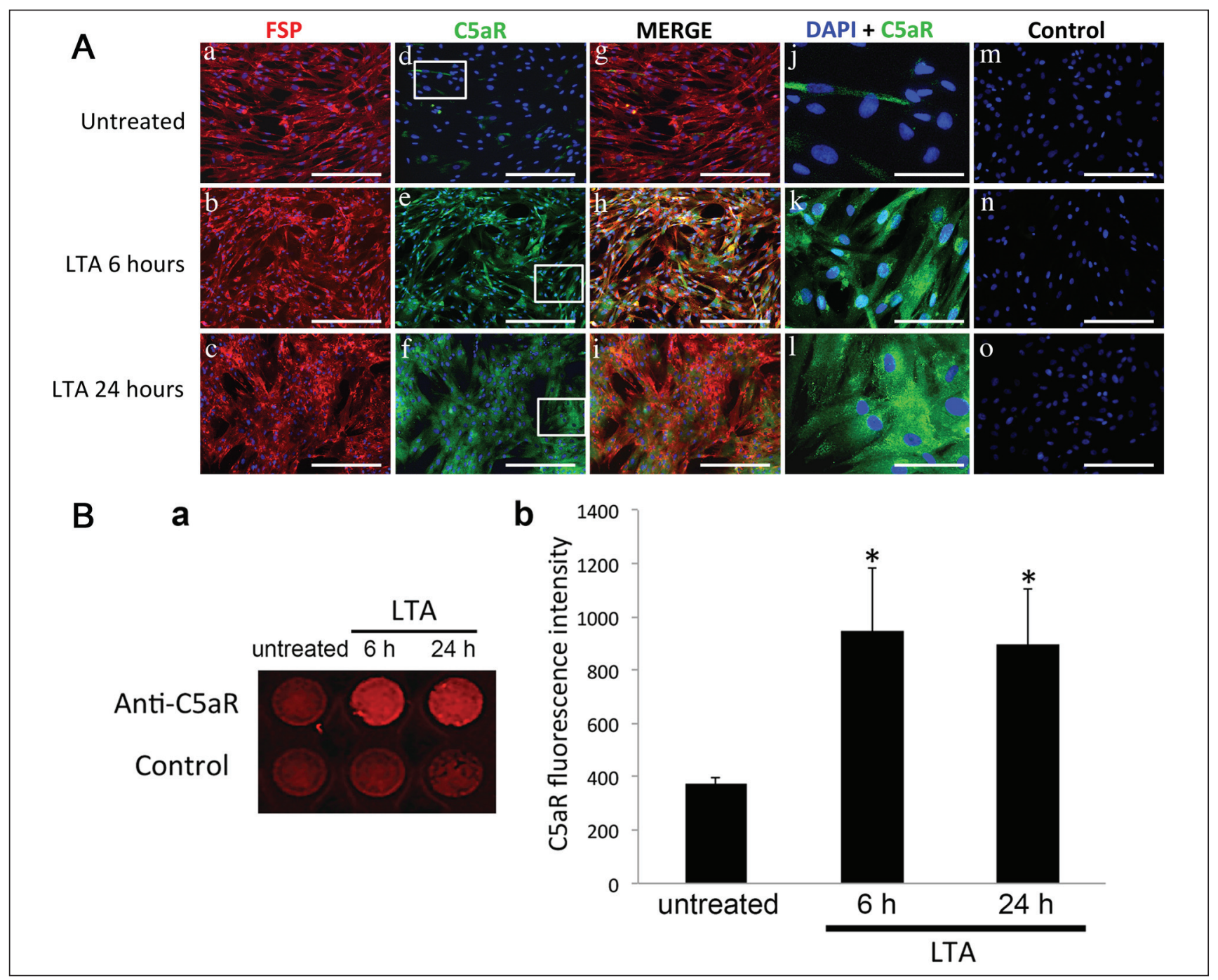

Figure 3. $\mathrm{C} 5 \mathrm{aR}$ expression in human pulp cells. (A) Immunofluorescence double staining was used to analyze C5aR expression in human pulp cells. Fibroblast surface protein (FSP) was detected on the surface of all human pulp cells $(a-c$ and $g-i)$. These pulp fibroblasts expressed few $C 5 a R$ in the untreated condition ( $d, g$, and j), but an intense C5aR staining was detected after lipoteichoic acid (LTA) stimulation at $6 \mathrm{~h}(\mathrm{e}, \mathrm{h}$, and k) and $24 \mathrm{~h}$ (f, i, and I). A higher magnification of C5aR staining demonstrated a perinuclear localization $6 \mathrm{~h}$ after LTA stimulation ( $\mathrm{k}$ ) while, after $24 \mathrm{~h}$, the staining was mainly membranous and diffuse in the cytoplasm (I). For each condition, negative controls, performed by replacement of the FSP and C5aR primary antibodies with isotype controls, showed no labeling $(\mathrm{m}-\mathrm{o})$. Secondary antibody used to detect FSP was Alexa 594 (red), and C5aR detection was done with Alexa 488 (green); nuclei were counterstained with 4',6-diamidino-2-phenylindole (DAPI) (blue). j, k, and I magnified respectively from the box in $d$, e, and $\mathrm{f}$. Scale bars: $\mathrm{a}-\mathrm{i}$ and $\mathrm{m}-\mathrm{o}=200 \mu \mathrm{m} ; \mathrm{j}-\mathrm{I}=50 \mu \mathrm{m}$. (B) C5aR expression analysis by in-cell Western assay. (a) An in-cell Western assay representative picture realized at $700 \mathrm{~nm}$ with Odyssey $\mathrm{CLx}$ of the $\mathrm{C} 5 \mathrm{aR}$ expression in human pulp fibroblasts. Controls were performed by replacement of the primary antibody with isotype control. (b) Graphic representing the 700-nm fluorescence intensity detected in pulp fibroblasts in arbitrary units (AU). The graphic shows that fluorescence intensities of C5aR were significantly higher in LTA-stimulated pulp fibroblasts (LTA) than in untreated pulp fibroblasts (untreated: $374.42 \pm$ 19.52; LTA 6 h: $946.43 \pm 239.10$; LTA 24 h: $895.47 \pm 206.74 ; P<0.05, n=3$ ).

staining was detected in all pulp fibroblasts $24 \mathrm{~h}$ after LTA stimulation (Fig. 4Af-i). C5aR activation decreased when LTA-stimulated fibroblasts were incubated with a C5aRspecific antagonist (Fig. 4Ak-n). In-cell Western results (Fig. $4 \mathrm{Ba}, \mathrm{b})$ confirmed that $\mathrm{C} 5 \mathrm{aR}$ was activated in LTA-stimulated cells, since the phospho-C5aR intensity was significantly higher than in untreated fibroblasts (Fig. 4Bb: black histograms vs. red line) at 6 and $24 \mathrm{~h}$. The coincubation of LTAstimulated fibroblasts with W54011 significantly reduced the phospho-C5aR intensity (Fig. 4Bb: blue vs. black histograms) at the same delays. Since all experiments have been realized in serum-free media (to avoid the presence of any complement molecules), the obtained results show that the C5a generated by pulp fibroblasts under LTA-stimulation activates their newly expressed C5aR.

\section{C5aR Is Required for the Modulation of BDNF Secretion in LTA-Stimulated Fibroblasts}

We next investigated the potential implication of $\mathrm{C} 5 \mathrm{aR}$ in BDNF secretion (Fig. 5A). LTA stimulation led to a significant increase of BDNF secretion at 6,24 , and $48 \mathrm{~h}$ (blue vs. pink 


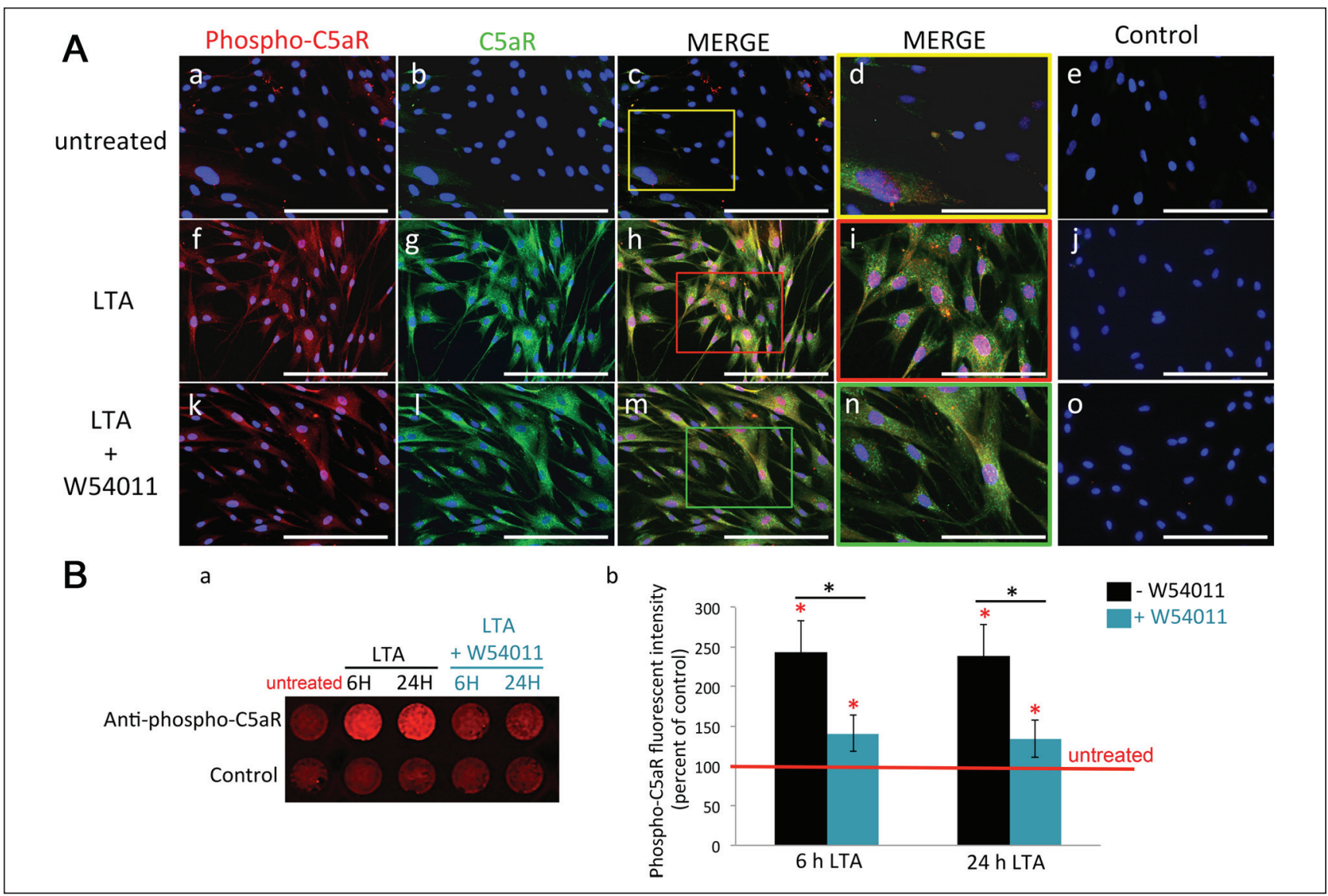

Figure 4. $C 5 a R$ activation in human pulp fibroblasts. (A) Double immunofluorescence staining realized to visualize the $C 5 a R(C 5 a R)$ and the $C 5 a R$ active form (phospho-C5aR) in human pulp fibroblasts. While few cells appeared positive for both phospho-C5aR and C5aR under unstimulated conditions ( $\mathrm{a}-\mathrm{d}$ ), all fibroblasts seemed to be positive for phospho-C5aR and C5aR after lipoteichoic acid (LTA) stimulation ( $\mathrm{f}-\mathrm{i}$ ). The coincubation of LTA-stimulated pulp fibroblasts with W540I I, a C5aR-specific antagonist, decreased the intensity of the phospho-C5aR staining (k-n). For each condition, negative controls, performed by replacement of the $\mathrm{C} 5 \mathrm{aR}$ and phospho-C5aR primary antibodies with isotype controls, showed no labeling (e, j, and o). Secondary antibody used to detect phospho-C5aR was Alexa 594 (red), and C5aR detection was done with Alexa 488 (green); nuclei were counterstained with 4',6-diamidino-2-phenylindole (DAPI) (blue). d, i, and n magnified respectively from the box in c, h, and m. Scale bars: a-c, e, f-h, $\mathrm{j}, \mathrm{k}-\mathrm{m}$, and $\mathrm{o}=200 \mu \mathrm{m} ; \mathrm{d}$, i, and $\mathrm{n}=100 \mu \mathrm{m}$. (B) Analysis of the C5aR activation by in-cell Western assay. (a) An in-cell Western assay representative picture realized at $700 \mathrm{~nm}$ with Odyssey CLx of the C5aR activation, detected through the C5aR serine338-phosphorylation, in pulp fibroblasts. (b) Graphic representing the $\mathrm{C} 5 \mathrm{aR}$ activation. For each experiment, the fluorescence intensity at $700 \mathrm{~nm}$ detected in untreated fibroblasts was arbitrarily fixed at $100 \%$ and is represented by the red line in the graphic. The stimulation of pulp fibroblasts with LTA significantly enhanced the quantity of activated $C 5 \mathrm{aR}$ both at $6 \mathrm{~h}$ and $24 \mathrm{~h}$ (red asterisks, $P<0.05 ; n=3$ ). However, the fluorescence intensity, which corresponds to the presence of phospo-C5aR in pulp fibroblasts, was reduced significantly when LTA-stimulated fibroblasts were coincubated with a C5aR-specific antagonist (black vs. blue histogram at 6-h and 24-h LTA stimulation corresponding to black asterisks; $P<0.05 ; n=3$ ).

histograms). Interestingly, the coincubation of LTA-stimulated fibroblasts with a C5aR-specific antagonist drastically decreased the secretion of this factor at 6,24 , and $48 \mathrm{~h}$ (green vs. blue histograms). These results show that $\mathrm{C} 5 \mathrm{aR}$ activation is directly implicated in the modulation of BDNF secretion by LTAstimulated fibroblasts. Surprisingly, incubation of LTAstimulated fibroblasts with an additional source of C5a for 6, 24, or $48 \mathrm{~h}$ had no effect on BDNF secretion (black vs. blue histograms). These data suggest that the C5a, generated by LTA-stimulated fibroblasts (Chmilewsky, Jeanneau, Laurent, et al. 2014), is sufficient to activate the newly expressed C5aR efficiently. Moreover, in agreement with our previous results showing that only few fibroblasts express C5aR, the stimulation of these cells with recombinant $\mathrm{C} 5 \mathrm{a}$ did not affect the basal BDNF secretion level (pink vs. gray histograms). These results show that the activation of the newly expressed C5aR is directly implicated in BDNF secretion by LTA-stimulated fibroblasts.

\section{C5aR of LTA-Stimulated Fibroblasts Is Responsible for Neurite Outgrowth via Local BDNF Secretion}

When pulp fibroblasts were cultured in the 2 peripheral chambers (Fig. 5Ba), the neurite outgrowth inside the microgrooves over a 48 -h period was random and $\beta$-III-tubulin staining was the same on both sides of the central channel and the microgrooves (Fig. 5Bb, c). The statistical analysis demonstrated that global neurite outgrowth was in the center of the graph 
(Fig. 5Bd). In accordance with our previous results, which show that $\mathrm{C} 5 \mathrm{aR}$ was not expressed by untreated fibroblasts, no effect was observed when the cells in one of the lateral chambers were stimulated only with $\mathrm{C} 5 \mathrm{a}$ (Fig. 5Be-h). However, when pulp fibroblasts in one of the lateral chambers were stimulated with LTA (Fig. 5Bi), the $\beta$-III-tubulin staining was mainly detected in the stimulation side (Fig. $5 \mathrm{Bj}$ ); the neurite trajectories (Fig. 5Bk) and the statistical analysis (Fig. 5Bl) showed that the global neurite outgrowth was significantly shifted toward the LTA stimulation side. The neurite outgrowth was drastically reduced with the C5aR-specific antagonist (Fig. 5Bm) and seemed to be redirected into the opposite side (Fig. 5Bn, o). This was confirmed by the shift of the global neurite outgrowth into the direction of untreated fibroblasts (Fig. 5Bp). These results demonstrated that the neurite recruitment in the direction of the LTA-injured site was dependent on the activation of pulp fibroblasts C5aR. Interestingly, the coincubation of neurons with an antagonist of tropomyosin receptor kinase B (TrkB) (Fig. 5Bq), a neuron's receptor known to induce neurite outgrowth through its interaction with BDNF (Shih et al. 2013), reduced the neurite outgrowth to the LTAstimulated side. The $\beta$-III-tubulin staining (Fig. 5Br) and representative neurite trajectories (Fig. 5Bs) appeared equally distributed toward untreated and LTA-stimulated cells. Indeed, the statistical analysis showed no significant displacement of the global neurite outgrowth (Fig. 5Bt), indicating that the neurite recruitment by LTA-stimulated fibroblasts was dependent on local BDNF secretion.

\section{Discussion}

In this study, we identified $\mathrm{C} 5 \mathrm{a} / \mathrm{C} 5 \mathrm{aR}$ as a key initial signal in dental nerve sprouting in carious teeth. Our study reveals that pulp fibroblasts express C5aR in case of carious injury both in vivo and after LTA stimulation in vitro. We demonstrate that this newly expressed $\mathrm{C} 5 \mathrm{aR}$ can be activated by $\mathrm{C} 5 \mathrm{a}$ generated from complement activation by pulp fibroblasts. We provide direct evidence of $\mathrm{C} 5 \mathrm{aR}$ critical implication in BDNF secretion modulation by pulp fibroblasts leading to a significant neurite outgrowth enhancement toward the injured site.

$\mathrm{C} 5 \mathrm{a}$ is a major component of innate immunity, playing a critical role in the inflammatory process (Cruvinel et al. 2010). This fragment, which is quickly generated by the complement activation, is known to exert a chemotactic action on inflammatory cells through its interaction with C5aR (Klos et al. 2009; Ward 2009; Ricklin et al. 2010). Consistent with these data, we detected a high level of C5aR in the inflammatory areas of carious teeth. An observation of these teeth sections at higher magnifications revealed that all pulp cells localized beneath the injured sites and expressed C5aR, suggesting a potential C5aR expression by nonimmune cells in case of carious injury. Interestingly, many nonimmune cells from various tissues express C5aR either constitutively or in response to stimuli (Monk et al. 2007). Thus, our study adds the human pulp fibroblast as a new nonimmune cell able to express C5aR in response to external stimulations, since C5aR has mainly been detected all around the nucleus $6 \mathrm{~h}$ after LTA stimulation and in the cytoplasm and at the cell membrane after stimulation for $24 \mathrm{~h}$. These data are supported by in-cell Western assays, which revealed a significant $\mathrm{C} 5 \mathrm{aR}$ expression in pulp fibroblasts after LTA stimulation for 6 and $24 \mathrm{~h}$. C5aR expression by various nonimmune cells suggested that the complement was implicated in other processes than inflammation. Indeed, several studies demonstrated that complement, particularly C5a, constitutes an important mediator of tissue regeneration (Ignatius et al. 2011; Mastellos et al. 2011; Lara-Astiaso et al. 2012). More recently, it has been demonstrated that C5a induces the recruitment of pulp progenitor cells (Chmilewsky et al. 2013; Chmilewsky, Jeanneau, Laurent, et al. 2014; Chmilewsky et al. 2015).

It is clearly established that dentin-pulp regeneration is a locally regulated process by the microenvironment modification (About 2013; Chmilewsky, Jeanneau, Dejou, et al. 2014). In case of carious injury, the acidic dissolution of dentin induces the liberation of extracellular matrix molecules and several growth factors directly implied in the dentin-pulp regeneration (Sloan and Smith 1999; Sloan et al. 2000). Moreover, the odontoblasts have also been identified as a source of regeneration signals in case of carious injury (Botero et al. 2006). However, deep carious injuries lead to the disintegration of odontoblasts beneath the injured sites (Fitzgerald et al. 1990). Interestingly, fibroblasts, which represent the major cell population within the pulp tissue, have previously been identified as a source of regeneration signals in case of traumatic injury (Tran-Hung et al. 2008). However, their ability to secrete regeneration signals in case of carious injury has not been given much attention. Our work highlights that BDNF secretion by cultured pulp fibroblasts was significantly enhanced after their incubation with LTA at 6, 24, and 48 h. Previous studies demonstrated that $\mathrm{C} 5 \mathrm{a}$ directly affects the secretion of several growth factors in various nonimmune cells (Boor et al. 2007; Cheng et al. 2013). In accordance with these data, we demonstrated that $\mathrm{C} 5 \mathrm{aR}$ acts as a positive regulator for BDNF as confirmed by W54011, which inhibited BDNF secretion by LTA-stimulated fibroblasts. Recently, human pulp fibroblast has been identified as the first nonimmune cell able to produce all complement molecules required for efficient complement activation after LTA stimulation, implying the production of C5a (Chmilewsky, Jeanneau, Laurent, et al. 2014). Here, we show, through phospho-C5aR staining in serum-free conditions, that the C5a generated by complement activation from molecules produced by LTA-stimulated fibroblasts activates its newly expressed C5aR. This is confirmed by W54011, which drastically decreases the C5aR-active form in LTA-stimulated fibroblasts. Moreover, BDNF quantification demonstrated that the C5a generated by LTA-stimulated fibroblasts (Chmilewsky, Jeanneau, Laurent, et al. 2014) is sufficient to control BDNF secretion level efficiently. Indeed, the use of an additional source of C5a to LTA-stimulated fibroblasts had no effect on BDNF secretion. In addition, the absence of a C5a effect on BDNF secretion by untreated cells confirmed that $\mathrm{C} 5 \mathrm{aR}$ is involved in BDNF modulation only after LTA stimulation. 


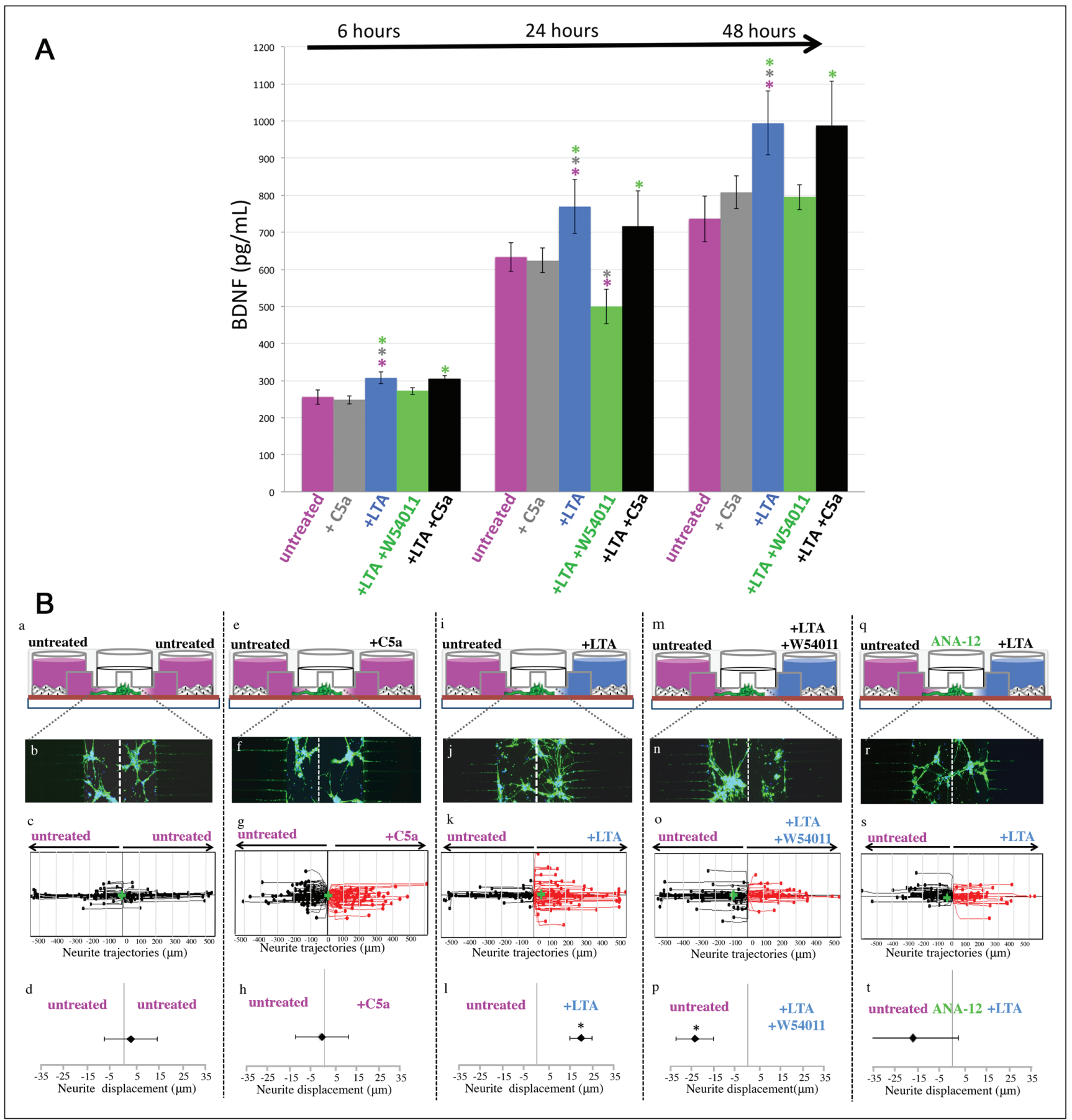

Figure 5. The interaction between $\mathrm{C5}$ a and lipoteichoic acid (LTA)-stimulated pulp fibroblasts controls the neurite outgrowth through the brainderived neurotropic factor (BDNF) modulation. (A) BDNF quantification in pulp fibroblast supernatants. BDNF was measured by enzyme-linked immunosorbent assay in pulp fibroblast supernatants after 6,24 , and $48 \mathrm{~h}$ and reported in $\mathrm{pg} / \mathrm{mL}$. For each experiment and for each condition, the quantity of BDNF was normalized to the cell viability. The quantity of BDNF measured in untreated fibroblast supernatants increased from 6 to $48 \mathrm{~h}$. The addition of $\mathrm{C} 5 \mathrm{a}$ to unstimulated cells $(+\mathrm{C} 5 \mathrm{a})$ has no effect on BDNF secretion. Fibroblast stimulation with LTA (+LTA) significantly increased BDNF secretion at 6,24 , and $48 \mathrm{~h}(P<0.05)$. This BDNF secretion significantly decreased when W540II was added to LTA-stimulated cells $(+\mathrm{LTA}+\mathrm{W} 540$ II $)(P<0.05)$ at the same delays. The addition of C5a to LTA-stimulated fibroblasts $(+\mathrm{LTA}+\mathrm{C} 5 \mathrm{a})$ had no effect on the BDNF secretion. (B) Effect of LTA-stimulated fibroblast C5aR on human neurite outgrowth. a, e, i, $\mathrm{m}$, and q: schematic representations of neurite outgrowth assays. b, f, j, n, and r: representative $\beta$-III-tubulin staining picture taken after 48 h. c, g, k, o, and s: representative plots of neuritis trajectories over a 48 -h period. For each representative plot, the green cross indicates the global direction of neurite outgrowth and corresponds, for each experiment, to the average of all neurite trajectories. Black and red trajectories correspond to the neurite outgrowth realized respectively toward the untreated and LTA-stimulated pulp fibroblasts. $\mathrm{d}, \mathrm{h}, \mathrm{l}, \mathrm{p}$, and t: statistical analysis of neurite outgrowth assays after $48 \mathrm{~h}$. Graphics represent global direction of neurite outgrowth; for each neurite outgrowth experiment, the average of all neurite lengths provided a dot corresponding to the global direction of 
Neurotrophins are essential for the development and functional maintenance of the nervous system, participating in axonal growth and nerve sprouting (Bothwell 2014). It became evident that their upregulation after injury constitutes a critical step in tissue regeneration (Gordon 2009). The possibility to culture 2 different cell types inside the same AXIS devices and to submit neurons to 2 different stimulation gradients (Park et al. 2006) allowed us to evaluate the effects of C5aR activation by LTA-stimulated pulp fibroblasts on the neurite outgrowth. We demonstrated that neurite outgrowth occurs in the direction of LTA-stimulated fibroblasts. These data are consistent with our in vivo results showing a high level of nerve fibers on the injured pulp of deep carious teeth. So, the present study provides, for the first time, evidence of an efficient interaction between pulp fibroblasts and nerve sprouting during the dentin-pulp regeneration. Interestingly, our results revealed that $\mathrm{C} 5 \mathrm{aR}$ controls the neurite outgrowth induced by LTAstimulated fibroblasts, since C5aR functional inhibition reduces drastically the neurite outgrowth in the direction of the LTA stimulation. This is correlated with the nerve sprouting and $\mathrm{C} 5 \mathrm{aR}$ colocalization observed beneath the injuries of human carious teeth. BDNF is known as a major neurite outgrowth inducer through its receptor TrkB (Shih et al. 2013; Yang et al. 2015). Our results suggest that the neurite outgrowth observed after LTA stimulation of pulp fibroblasts is guided by BDNF. Indeed, the coincubation of neurons with a TrkB-inhibitor prevented this neurite outgrowth. This could explain why, when LTA-stimulated fibroblasts were coincubated with W54011, the neurites outgrew in the direction of untreated cells. Indeed, BDNF quantification revealed that the inhibition of a C5a-C5aR interaction drastically reduced the BDNF secretion by LTA-stimulated pulp fibroblasts. Thus, the BDNF secreted by LTA-stimulated cells in the presence of W54011 detected at $24 \mathrm{~h}$ was inferior to that secreted by untreated fibroblasts. These results also suggest that C5aR activation might be implicated in the regulation of other molecules implied in neurite outgrowth. Although poorly understood, previous studies suggested that nerve growth factor (NGF) upregulation could be responsible for dental nerve sprouting (Byers et al. 1992). Here, we bring additional data in the comprehension of this event by demonstrating that LTA-stimulated fibroblasts mediated the enhancement of neurite outgrowth via the BDNF upregulation and its orchestration by the C5aR. This work is in concordance with previous studies, demonstrating in vitro that pulp cells secrete neurotrophins, which are known to induce nerve growth from the trigeminal ganglion into the pulp in vivo (Lillesaar et al. 1999).

Our findings highlight a new mechanism in dentin-pulp regeneration, linking, for the first time, pulp fibroblast to the nerve sprouting through the complement activation. In this mechanism, the BDNF modulation by human pulp fibroblasts localized beneath the injured site, through the C5a-C5aR interaction, could locally induce a neurite outgrowth/increased nerve sprouting, which is required for efficient dentin-pulp regeneration (Byers and Taylor 1993). Thus, these results may provide a useful future therapeutic tool in targeting the fibroblasts in dentin-pulp regeneration.

\section{Author Contributions}

F. Chmilewsky, contributed to conception, design, data acquisition, analysis, and interpretation, drafted and critically revised the manuscript; I. About, contributed to design, data analysis, and interpretation, drafted and critically revised the manuscript; S.-H. Chung, contributed to data interpretation, critically revised the manuscript. All authors gave final approval and agree to be accountable for all aspects of the work.

\section{Acknowledgments}

We thank Dr. Jean-Charles Gardon for providing the third molars and Dr. David A. Reed from the department of Oral Biology, University of Illinois at Chicago, for kindly providing the microscope (Leica DM2000) used for generated histologic pictures. This study was supported by start-up funds from University of Illinois at Chicago College of Dentistry (to S.-H. Chung). The authors declare no potential conflicts of interest with respect to the authorship and/or publication of this article.

\section{References}

About I. 2013. Dentin-pulp regeneration: the primordial role of the microenvironment and its modification by traumatic injuries and bioactive materials. Endod Topics. 28(1):61-89.

About I, Bottero MJ, de Denato P, Camps J, Franquin JC, Mitsiadis TA. 2000. Human dentin production in vitro. Exp Cell Res. 258(1):33-41.

Arai H. 1991. Neurohistological study on responses of nerve fibers to pulpitis in human teeth. Jap J Conserv Dent. 34:1631-1646.

Boor P, Konieczny A, Villa L, Schult AL, Bücher E, Rong S, Kunter U, van Roeyen CR, Polakowski T, Hawlisch H, et al. 2007. Complement C5 mediates experimental tubulointerstitial fibrosis. J Am Soc Nephrol. 18(5):1508-1515.

Botero TM, Shelburne CE, Holland GR, Hanks CT, Nör JE. 2006. TLR4 mediates LPS-induced VEGF expression in odontoblasts. J Endod. 32(10):951-955.

Bothwell M. 2014. NGF, BDNF, NT3, and NT4. Handb Exp Pharmacol 220:3-15.

Byers MR, Nähri MV. 1999. Dental injury models: experimental tools for understanding neuroinflammatory interactions and polymodal nociceptor functions. Crit Rev Oral Biol Med. 10(1):4-39.

Byers MR, Taylor PE. 1993. Effect of sensory denervation on the response of rat molar pulp to exposure injury. J Dent Res. 72(3):613-618.

Byers MR, Wheeler EF, Bothwell M. 1992. Altered expression of NGF and p75-NGF receptor mRNA by fibroblasts of injured teeth precedes sensory nerve sprouting. Growth Factors. 6(1):41-52.

Cheng L, Bu H, Portillo JA, Li Y, Subauste CS, Huang SS, Kern TS, Lin F. 2013. Modulation of retinal Müller cells by complement receptor C5aR Invest Ophthalmol Vis Sci. 54(13):8191-8198.

the neurite outgrowth. No neurite outgrowth-specific direction was observed in the absence of LTA stimulation $(2.87 \pm 11.18 \mu \mathrm{m})(\mathrm{d})$ or when the fibroblasts of the right chamber were stimulated with C5a $(-0.99 \pm 8.84 \mu \mathrm{m})(\mathrm{h})$. When pulp fibroblasts of the right chamber were stimulated with LTA, the dot significantly shifted toward the right, indicating that neurite growth was preferentially shifted toward LTA stimulation (I9.7I $\pm 4.95 \mu$ m; $* P<$ $0.05 ; n=3)(I)$. The coincubation of LTA-stimulated fibroblasts with W540I I significantly reduced the neurite outgrowth toward the LTA stimulation; the dot significantly shifted toward the untreated fibroblasts, indicating that the neurite outgrowth occurred toward the opposite side $(-23.91 \pm 8.53$ $\mu \mathrm{m} ; * \mathrm{P}<0.05 ; n=3)(\mathrm{P})$. The incubation of neurons with ANA-I2 abolished the neurite outgrowth toward LTA-stimulated fibroblasts $(-17.32 \pm 32.44$ $\mu \mathrm{m} ; P<0.05 ; n=3)(\mathrm{t})$. 
Chmilewsky F, Jeanneau C, Dejou J, About I. 2014. Sources of dentin-pulp regeneration signals and their modulation by the local microenvironment J Endod. 40(4 Suppl):S19-S25.

Chmilewsky F, Jeanneau C, Laurent P, About I. 2014. Pulp fibroblasts synthesize functional complement proteins involved in initiating dentine pulp regeneration. Am J Pathol. 184(7):1991-2000.

Chmilewsky F, Jeanneau C, Laurent P, About I. 2015. LPS induces pulp progenitor cell recruitment via complement activation. J Dent Res. 94(1):166174.

Chmilewsky F, Jeanneau C, Laurent P, Kirschfink M, About I. 2013. Pulp progenitor cell recruitment is selectively guided by a C5a gradient. J Dent Res. 92(6):532-539.

Cruvinel Wde M, Mesquita D Jr, Araújo JA, Catelan TT, de Souza AW, da Silva NP, Andrade LE. 2010. Immune system - part I: fundamentals of innate immunity with emphasis on molecular and cellular mechanisms of inflammatory response. Rev Bras Reumatol. 50(4):434-461.

Fitzgerald M, Chiego DJ Jr, Heys DR. 1990. Autoradiographic analysis of odontoblast replacement following pulp exposure in primate teeth. Arch Oral Biol. 35(9):707-715.

Gordon T. 2009. The role of neurotrophic factors in nerve regeneration. Neurosurg Focus. 26(2):E3.

Hanoun M, Maryanovich M, Arnal-Estapé A, Frenette PS. 2015. Neural regulation of hematopoiesis, inflammation, and cancer. Neuron. 86(2):360 373.

Ignatius A, Schoengraf P, Kreja L, Liedert A, Recknagel S, Kandert S, Brenner RE, Schneider M, Lambris JD, Huber-Lang M. 2011. Complement C3a and C5a modulate osteoclast formation and inflammatory response of osteoblasts in synergism with IL-1b. J Cell Biochem. 112(9):2594-2605.

Kimberly CL, Byers MR. 1988. Inflammation of rat molar pulp and periodontium causes increased calcitonin gene-related peptide and axonal sprouting. Anac Rec. 222(3):289-300.

Kloner RA, Fishbein MC, Lew H, Maroko PR, Braunwald E 1978. Mummification of the infarcted myocardium by high dose corticosteroids. Circulation. 57(1):56-63.

Klos A, Tenner AJ, Johswich KO, Ager RR, Reis ES, Köhl J. 2009. The role of the anaphylatoxins in health and disease. Mol Immunol. 46(14):2753-2766.

Lara-Astiaso D, Izzara A, Estrada JC, Albo C, Moscoso I, Samper E, Moncayo J, Solano A, Bernard A, Díez-Juan A. 2012. Complement anaphylatoxins $\mathrm{C} 3 \mathrm{a}$ and $\mathrm{C} 5 \mathrm{a}$ induce a failing regenerative program in cardiac resident cells: evidence of a role for cardiac resident stem cells other than cardiomyocyte renewal. Springerplus. 1(1):63-78.

Lillesaar C, Eriksson C, Johansson CS, Fried K, Hildebrand C. 1999. Tooth pulp tissue promotes neurite outgrowth from rat trigeminal ganglia in vitro. J Neurocytol. 28(8):663-670.
Martin FE, Nadkarni MA, Jacques NA, Hunter N. 2002. Quantitative microbiological study of human carious dentine by culture and real-time PCR: association of anaerobes with histopathological changes in chronic pulpitis. J Clin Microbiol. 40(5):1698-1704.

Mastellos D, Papadimitriou JC, Franchini S, Tsonis PA, Lambris JD. 2011. A novel role of complement: mice deficient in the fifth component of complement (C5) exhibit impaired liver regeneration. J Immunol. 166(4):24792486.

Monk PN, Scola AM, Madala P, Fairlie DP. 2007. Function, structure and therapeutic potential of complement $\mathrm{C} 5 \mathrm{a}$ receptors. $\mathrm{Br} \mathrm{J}$ Pharmacol. 152(4):429-448

Park JW, Vahidi B, Taylor AM, Rhee SW, Jeon NL. 2006. Microfluidic culture platform for neuroscience research. Nat Protoc. 1(4):2128-2136.

Ricklin D, Hajishengallis G, Yang K, Lambris JD. 2010. Complement: a key system for immune surveillance and homeostasis. Nat Immunol. 11(9):785-797.

Shih CH, Chen CJ, Chen L. 2013. New function of the adaptor protein SH2B1 in brain-derived neurotrophic factor-induced neurite outgrowth. PLoS One. 8(11):e79619.

Sloan AJ, Rutherford RB, Smith AJ. 2000. Stimulation of the rat dentinepulp complex by bone morphogenetic protein-7 in vitro. Arch Oral Biol. 45(2):173-177.

Sloan AJ, Smith AJ. 1999. Stimulation of the dentine-pulp complex of rat incisor teeth by transforming growth factor-beta isoforms 1-3 in vitro. Arch Oral Biol. 44(2):149-156.

Tao T, Chen C, Sun J, Peng Y, Zhu M. 2015. A bacterial artificial chromosome transgenic mouse model for visualization of neurite growth. Sci China Life Sci. 58(4):373-378.

Taylor PE, Byer MR, Redd PE. 1988. Sprouting of CGRP nerve fibers in response to dentin injury in rat molars. Brain Res. 461(2):371-376.

Téclès O, Laurent P, Zygouritsas S, Burger AS, Camps J, Dejou J, About I. 2005. Activation of human dental pulp progenitor/stem cells in response to odontoblast injury. Arch Oral Biol. 50(2):103-108.

Tran-Hung L, Laurent P, Camps J, About I. 2008. Quantification of angiogenic growth factors released by human dental cells after injury. Arch Oral Biol. 53(1):9-13.

Ward PA. 2009. Functions of C5a receptors. J Mol Med (Berl). 87(4):375-378.

Woodnutt DA, Wager-Miller J, O’Neill PC, Bothwell M, Byers MR. 2000. Neurotrophin receptors and nerve growth factor are differentially expressed in adjacent nonneuronal cells of normal and injured tooth pulp. Cell Tissue Res. 299(2):225-236.

Yang JW, Ru J, Ma W, Gao Y, Liang Z, Liu J, Guo JH, Li LY. 2015. BDNF promotes the growth of human neurons through crosstalk with $\mathrm{Wnt} / \beta$ catenin signaling pathway via GSK-3 $\beta$. Neuropeptides. 54:35-46. 